\title{
Auto Whatsapp Sebagai Alternatif Layanan Perpustakaan pada Masa Pandemi Covid-19 di IAIN Curup
}

\author{
Maisonah \\ Institut Agama Islam Negeri (IAIN) Curup \\ dionasona@gmail.com
}

\begin{abstract}
Library is to develop knowledge and information. Every information and knowledge in a library is obtained from several media; such as books; magazines; brochures; computers use networks and journals. Library services are management to manage all media information and knowledge. In March 2020 the Covid-19 enter Indonesia. One way to assist the government in preventing the spread of Covid-19 is to eliminate face-to-face lectures. In addition; library services are removed. Therefore; in order to keep library services running; one alternative is to use Auto WhatsApp. This application helps students in obtaining library services especially in obtaining a Fractivator-Free Library Information (CFL). The results of largescale trials of SKBPP services with autowhatsapp to 73 users' responses resulted in $98.6 \%$ stating that users were satisfied with the service; $95.9 \%$ of users stated that SKBPP services with autowhtasapp were effective; $97.3 \%$ users easily used the application; 95.9\% users stated that the information on the service was clear; and $97.3 \%$ of users stated that the use of sentences in autowhatsapp was easy to understand. From the research; it is concluded that Auto WhatsApp can be used as an alternative service during the Covid-19 pandemic and further development is needed.
\end{abstract}

Keywords : Auto WhatsApp; Application; library services; Certificate.

\begin{abstract}
Abstrak
Perpustakaan adalah sarana untuk mengembangkan pengetahuan dan informasi.Setiap informasi dan pengetahuan di perpustakaan diperoleh dari beberapa media; seperti buku; majalah; brosur; komputer dengan jaringan dan jurnal. Layanan perpustakaan merupakan manajemen untuk mengelola seluruh media informasi dan pengetahuan. Pada bulan maret 2020 wabah Covid-19 mulai masuk ke Indonesia. Salah satu cara membantu pemerintah dalam pencegahan penyebaran Covid-19 adalah meniadakan perkuliahan tatap muka. Selain itu; layanan perpustakaan ditiadakan. Penelitian ini bertujuan pengembangan applikasi auto whatsapp sebagai alternatif layanan SKBPP perpustakaan. Metode penelitian yang digunakan adalah penelitian
\end{abstract}


pengembangan. Uji coba skala kecil dilakukan terhadap 20 pemustakan sedangkan ujicoba skala besar dilakukan terhadap 73 pemustaka. Hasil uji coba skala besar terhadap layanan SKBPP dengan autowhatsapp kepada respon 73 pemustaka dihasilkan 98;6\% menyatakan pemustaka puas dengan layanan; 95;9 \% pemustaka menyatakan layanan SKBPP dengan autowhtasapp efektif; 97;3\% pemustaka mudah menggunakan applikasi; 95;9\% pemustaka menyatakan informasi pada layanan jelas; dan 97;3\% pemustaka menyatakan penggunaan kalimat pada autowhatsapp mudah dipahami. Dari penelitian disimpulkan Auto whatsapp dapat digunakan sebagi alternative layanan di masa pandemic covid-19 dan perlu dilakukan pengembangan lebih lanjut.

Kata Kunci : Auto WhatsApp; Aplikasi; Layanan Perpustakaan; Surat Keterangan Bebas Pinjaman Perpustakaan (SKBPP)

\section{A. PENDAHULUAN}

Wabah Covid-19 adalah salah satu penyakit disebabkan oleh virus yang menyerang organ paru-paru manusia. Virus ini menular sangat cepat sehingga perlu pencegahan dan penanganan khusus. Kasus Covid-19 terjadi di Indonesia pada bulan maret 2020. Akibat menyebar virus Covid-19 maka IAIN Curup mengambil beberapa keputusan untuk membantu pemerintah mencegah penyebaran Covid-19. Salah satu keputusan adalah mengubah layanan perpustakaan yang biasanya mahasiswa datang ke perpustakaan menjadi layanan bersifat online atau daring (dalam jaringan). Hasil penelitian karim di dalam Jurnal Publis (Karim \& zakiyah, 2019) Pemanfaatan layanan Perpustakaan di Indonesia semakin tahun semakin meningkat dengan menggunakan teknologi informasi serta Pemerintah Indonesia melalui Perpustakaan Nasional juga selalu berusaha dengan membuat layanan yang inovatif; memberikan kemudahaan untuk masyarakat dalam memenuhi kebutuhan informasinya. Selain itu diharapkan dengan adanya layanan layanan menggunakan teknologi yang sudah diluncurkan oleh Pemerintah masyarakat Indonesia dapat meningkatkan minat baca.

Kebutuhan informasi pemustaka di era industri 4.0 sangat kompleks. Pemustaka semakin tertarik akan informasi sebagai salah satu upaya untuk pengembangan diri. Selain itu; dengan perkembangan teknologi maka pemustaka seharusnya lebih mudah memperoleh layanan yang berhubungan dengan informasi. Dalam era global dibutuhkan gabungan antara kreativitas dan profesional; dimana satu sama lain saling mengisi kekosongan dan 
memperkuat; sehingga dapat memenuhi kebutuhan para pemakai sesuai dengan bidangnya. Berkembangnya teknologi media dapat memacu perkembangan dan kemampuan pustakawan dalam mengolah informasi (Nashihudin, 2016).

Informasi berbasis multimedia sangat disukai para pemakai karena dapat dilihat; didengar; dan dicoba sehingga informasi yang disampaikan akan lebih cepat diserap dan dipahami oleh para pemakai. Kemampuan para pustakawan dalam era global perlu ditingkatkan; terutama yang berhubungan dengan aplikasi teknologi informasi; termasuk multimedia di bidang perpustakaan dan dokumentasi; sehingga layanan yang diberikan kepada para pemakai akan lebih cepat; tepat dan akurat (Karim \& zakiyah, 2019). Hal ini merupakan salah satu tantangan pustakawan untuk memberikan informasi dan kebutuhan pemustaka. Akan tetapi permasalahan bertambah di awal tahun 2020 dengan mewabahnya virus Covid-19.

Seiring dengan perkembangan teknologi informasi serta perubahan konsep perpustakaan konvensional ke teknologi perpustakaan; pemustaka menginginkan adanya kemudahan dalam penelusuran informasi (Andayani, 2009). Mengubah layanan perpustakaan berbasis online merupakan salah satu cara kemudahan dalam penelusuran informasi. Munculnya alat media sosial baru telah menciptakan kebutuhan bagi para profesional perpustakaan untuk mengembangkan keterampilan dan kompetensi baru. Sayangnya; banyak librarians tidak cukup membekali diri dengan semua keterampilan ini; karena tidak cukup bagi mereka untuk memahami cara menggunakan alat media sosial (Jones \& Harvey, 2016). Oleh sebab itu; sebagai pustakawan yang professional maka dituntut untuk kreatif dan inovatif. Karena indikator profesionalisme seorang pustakawan adalah rasa tanggung jawab dan keahlian dalam pengelolaan perpustakaan. Kedua indikator ini merupakan penentu menghasilkan solusi untuk memecahkan masalah. Selain itu; pustakawan perlu meningkatkan produktivitas dengan menghasilkan karya-karya yang bermanfaat bagi perpustakaan dan pemustaka. Di artikel ini akan dibahas salah satu pemanfaatan aplikasi platform WhatsApp untuk layanan perpustakaan khususnya proses pembuatan Surat Keterangan Bebas Pinjaman Perpustakaan (SKBPP).

Perpustakaan modern menekankan layanan yang optimal untuk memenuhi kebutuhan pengguna dan memfasilitasi interaksi antara 
perpustakaan dan pengguna. Di era Internet saat ini; media sosial tampaknya menjadi alat yang "mudah" bagi pustakawan untuk mempromosikan layanan dan koleksi mereka. Meskipun demikian; banyak perpustakaan yang merasa kesulitan untuk memanfaatkan media sosial dalam pemasaran (Hong, Tak Hei Lam, \& KW Chiu, 2020).

Layanan perpustakaan merupakan segala kegiatan yang menyediakan bahan pustaka (seperti buku; jurnal; dan karya ilmiah dan koleksi lainnya) yang dibutuhkan oleh pemustaka dalam hal ini di IAIN Curup adalah Dosen; Staf; Mahasiswa dan Masyarakat. Layanan perpustakaan IAIN Curup menggunakan layanan sistem terbuka (Open Access) dimana pemustaka atau user langsung mencari bahan pustaka yang sudah disediakan di perpustakaan; pemustaka bisa langsung ke jajaran koleksi ataupun browsing melalui komputer OPAC ( Online Public Access Catalog ). OPAC merupakan fasilitas pemustaka atau user untuk mempermudah mencari katalog bahan pustaka secara online.

Kegiatan layanan perpustakaan di IAIN Curup terdiri dari 2 (dua) bentuk layanan :

1. Layanan teknis; adalah layanan back office yaitu kegiatan yang berkaitan dengan pengadaan; pengolahan; persiapan dan pelestarian bahan pustaka.

2. Layanan pemustaka atau pengunjung; adalah layanan front office merupakan kegiatan perpustakaan seperti layanan sirkulasi; layanan referensi; layanan pendidikan pemustaka; dan layanan BI Corner; Rejang Corner; dan layanan website.

Perpustakaan digital adalah perpustakaan yang dalam manajemen perpustakaan menggunakan konsep internet dan teknologi informasi. Di era digital; perpustakaan berperan sebagai fasilitator bagi pemustaka dimana sebagi pengguna. Fungsi dari perpustakaan di era digital sebagai berikut (Rhoni, 2017):

1. Meningkatkan layanan perpustakaan yang berbasis kebutuhan pengguna; perkembangan teknologi informasi dan perkembangan ilmu pengetahuan.

2. Memperluas jaringan informasi.

3. Mempermudah akses ke dalam sumber-sumber informasi apapun bentuk dan jenisnya. 
4. Meningkatkan perkembangan secara sistematis; perangkat untuk mengumpulkan; menyimpan; dan mengatur informasi dan pengetahuan dalam bantuk digital.

5. Menciptakan sistem terintregasi yang lebih luas; terjangkau; dan mudah diakses oleh seluruh pengguna kapanpun dan dimanapun.

WhatsApp merupakan sebuah aplikasi seluler lintas platform Berbeda dengan aplikasi Short Message Service (SMS) yaitu fasilitas yang hanya bisa teks dan berbayar; maka aplikasi WA adalah gratis dan bisa mengirim tidak dalam bentuk teks saja melainkan juga bisa dalam bentuk gambar; pesan video dan audio dalam jumlah tidak terbatas. Lebih dari 1 miliar orang di lebih dari 180 negara menggunakan WA untuk tetap terhubung dengan teman dan keluarga; kapan saja dan di mana saja. WA gratis dan menawarkan kemampuan mengirim pesan dan melakukan panggilan yang sederhana; aman; dan reliabel; yang tersedia untuk telepon di seluruh dunia. Nama WA adalah pelesetan dari frasa What's Up; yang artinya Apa Kabar. WA dimulai sebagai alternatif untuk SMS (Pranajaya, 2017).

Secara sederhana pengertian WhatsApp adalah aplikasi pengiriman pesan dan lain-lain untuk smartphone. Dan lain-lain disini maksudnya bahwa aplikasi WhatsApp ini bisa untuk mengirim gambar; dokumen; teks; lokasi tempat dan suara video. Fungsi dasar WhatsApp hampir sama dengan Short Message Service (SMS) yang mulai jarang dipakai. Namun WhatsApp tidak menggunakan pulsa; melainkan data internet (Larasati, 2013). Di bawah ini adalah jenis aplikasi WhatsApp :

1. WhatsApp messenger; adalah aplikasi di smartphone yang berfungsi bertukar pesan; melakukan video call; dan Voice note tanpa menggunakan pulsa melainkan paket data.

2. WhatsApp bussines; adalah aplikasi yang digunakan para pemilik usaha. Pada aplikasi ini pengusaha dapat menampilkan produk; melakukan sortir; dan menjawab pesan secara cepat. Dalam whatsapp bussines ini terdapat katalog merupakan etalase bagi bisnis untuk menampilkan dan membagikan informasi produk agar pelanggan dapat dengan mudah menjelajah dan menemukan sesuatu yang ingin dibeli. Sebelumnya; pemilik bisnis harus mengirim foto produk satu per satu dan memberikan informasi berulang-ulang; sekarang pelanggan dapat melihat katalog lengkap bisnis di dalam WhatsApp. Fitur ini membuat 
pemilik bisnis tampak lebih profesional dan memungkinkan pelanggan terlibat dalam chat tanpa perlu mengunjungi situs web.

3. Auto WhatsApp; adalah aplikasi pesan otomatis. Setiap pesan yang masuk akan dibalas secara otomatis dengan pesan yang sudah diatur atau dibuat sebelumnya.

(www.whatsApp.com)

Jenis penelitian yang digunakan dalam penelitian ini adalah Research and Development. Metode digunakan untuk menghasilkan produk tertentu; dan menguji keefektifan produk tersebut (Sugiyono, 2009).Pengertian penelitian pengembangan menurut Borg and Gall "research and development is a powerful strategy for improving practice. It is a process used to develop and validate educational products ." Pengertian tersebut dapat dijelaskan bahwa "penelitian dan pengembangan merupakan strategi yang kuat untuk meningkatkan praktek. Itu adalah proses yang digunakan untuk mengembangkan dan memvalidasi produk ." Produk yang dimaksud dalam penelitian dan pengembangan mengandung empat pengertian pokok. Pertama; produk tersebut tidak hanya meliputi perangkat keras; seperti modul; buku teks; video dan film pembelajaran atau perangkat keras yang sejenisnya; tetapi juga perangkat lunak seperti kurikulum; evaluasi; model pembelajaran; prosedur dan proses pembelajaran; dan lain-lain, Kedua; produk tersebut dapat berarti produk baru atau memodifikasi produk yang sudah ada, Ketiga; produk yang dikembangkan merupakan produk yang betul-betul bermanfaat bagi dunia pendidikan dan perpustakaan, Keempat; produk tersebut dapat dipertanggungjawabkan; baik secara praktis maupun keilmuan (Arifin, 2012).

\section{B. HASIL DAN PEMBAHASAN}

Penelitian pengembangan bertujuan untuk mengambangkan suatu produk dan menguji produk yang dihasilkan. Prosedur penelitian ini terdiri dari empat tahap; yaitu (1) Tahap perencanaan; (2) Tahap Pengorganisasian; (3) Tahap pelaksanaan; dan (4) Tahap penilaian produk. 


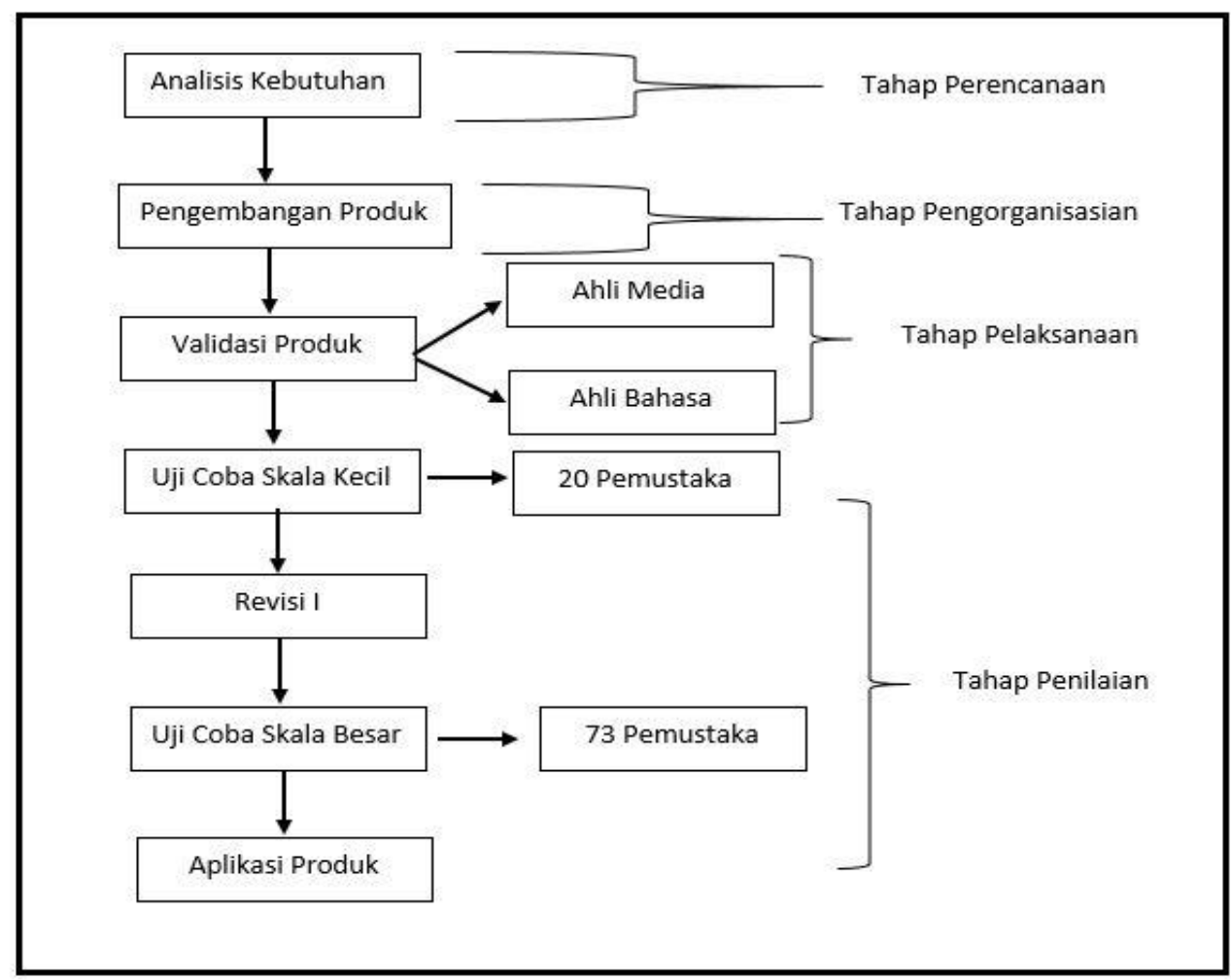

Gambar 1 : Tahap Pengembangan Dan Penilaian Produk

\section{Analisis Kebutuhan}

Tahap pertama dari penelitian yang dilakukan adalah peneliti melakukan analisis kebutuhan. Permasalahan yang dianalisis oleh peneliti adalah mewabahnya covid-19 yang menghambat proses layanan perpustakaan dengan teknis tatap muka. Dari hasil observasi; maka dibutuhkan teknis layanan jarak jauh atau online dalam melakukan layanan perpustakaan khususnya SKBPP.

\section{Pengembangan Produk Awal}

Pada tahap ini dilakukan langkah-langkah sistematis dalam proses pengembangan. Adapun langkah-langkah pengembangan sebagai berikut :

1. Pembuatan E mail admin layanan SKBPP;

2. Membuat data base pemustaka di Google Drive E mail admin;

3. Melakukan autocard antara data base dengan SKBPP;

4. Membuat pesan otomatis di Google Drive admin menggunaka spreadsheet;

5. Melakukan instalasi auto WhatsApp di smartphone android admin; 
202 | TIK ILMEU: Jurnal IImu Perpustakaan dan Informasi, vol. 4, no. 2, 2020

6. Melakukan sinkronisasi auto WhatsApp dengan database pemustaka di E mail admin.

\section{Validasi Produk}

Validasi produk dilakukan dengan meminta saran terhadap ahli media dan ahli bahasa. Instrumen yang digunakan berupa lembar kritik dan saran mengenai produk yang dikembangkan.

Tabel 1 : Validasi Ahli Media dan Ahli Bahasa

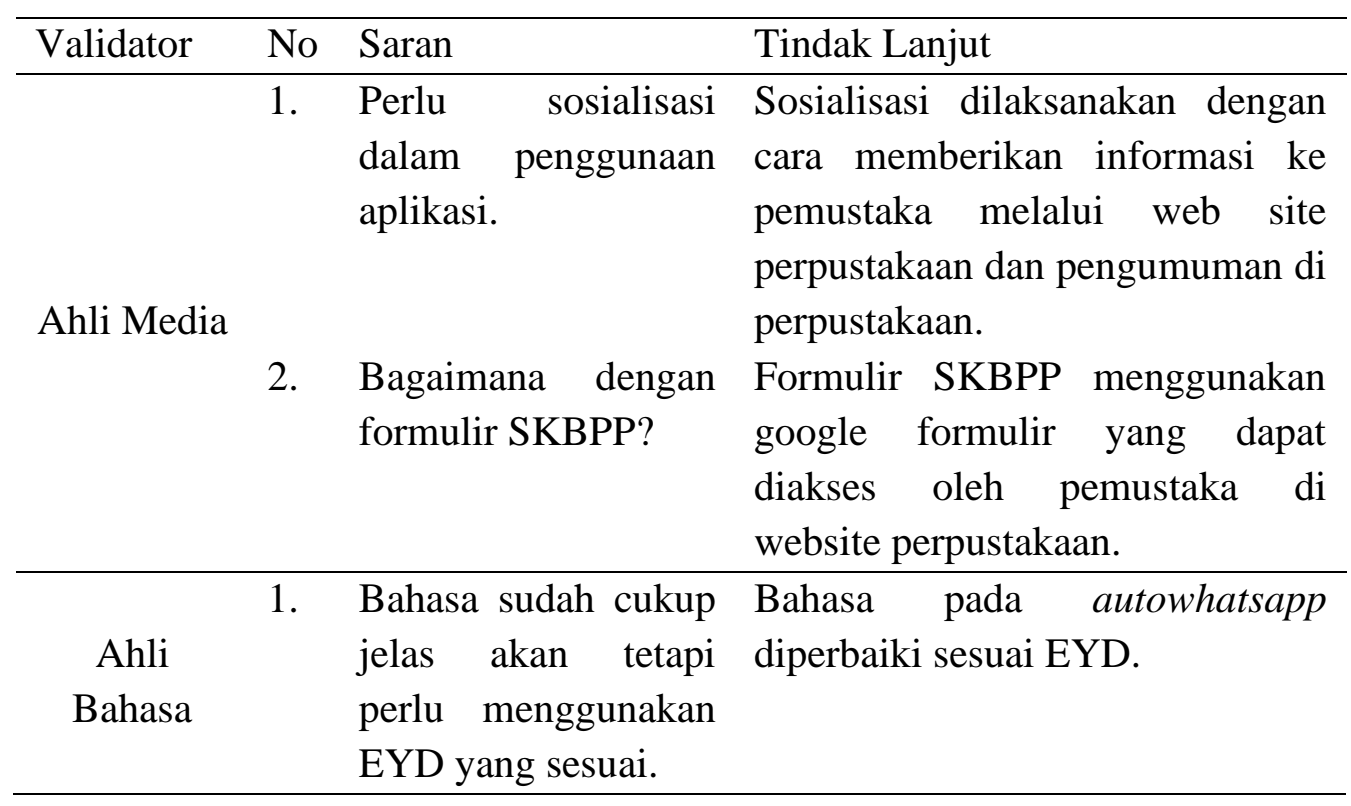

\section{Uji Coba Skala Kecil}

Uji coba skala kecil dilakukan kepada 20 pemustaka. Adapun ujicoba dengan teknis pemustaka menggunakan applikasi whatsapp dan mengirim pesan ke whatsapp admin layanan SKBPP. Setelah pemustaka melakukan ujicoba terhadap layanan SKBPP dengan auto whatsapp maka dilakukan penilaian terhadap layanan SKBPP dengan Whatsapp. Terdapat 5 aspek yang dinilai; yaitu (1) Kepuasan pengguna;(2) Efektifitas produk; (3) Kemudahan penggunaan aplikasi; (4) Kejelasan informasi (5) Kejelasan kalimat.

Metode yang digunakan pada uji coba skala kecli adalah metode mix method. Metode ini mengumpulkan data yang berupa kualitatif dan diubah menjadi kuantitatif dengan skala dua; yaitu setuju dan tidak setuju. Berdasarka uji coba skala kecil diperoleh hasil yaitu; Pada aspek kepuasaan pengguna $90 \%$ pemustaka merasa puas dalam pelayanan SKBPP menggunakan WhatsApp. Sedangkan $10 \%$ tidak puas dengan pelayanan SKBPP dengan WhatsApp Menurut hasil instrument angket; ketidak puasan 
pemustaka terhadap layanan SKBPP adalah jaringan yang kurang mendukung; sehingga dalam mengkases layanan mengalami kendala. Pada aspek efektifitas produk $90 \%$ pemustaka menyatakan layanan SKBPP dengan WhatsApp efektif. Pada aspek kemudahan penggunaan produk $90 \%$ pemustaka menyatakan setuju. Aspek kejelasan informasi yang diberikan 80 $\%$ pemustaka setuju dan $20 \%$ pemustaka tidak setuju. Dari aspek ini; pemustaka tidak setuju informasi yang diberikan jelas karena perintah yang diberikan pesan belum jelas. Sedangkan ada aspek penggunaan kalimat mudah dipahami $80 \%$ pemustaka setuju kalimat mudah dipahami dan $20 \%$ tidak setuju.

Hasil uji coba skala kecil dijadikan bahan evaluasi dan revisi produk. Aspek yang diperbaiki adalah aspek kepuasan pengguna; aspek efektifitas produk; kemudahan produk; aspek kejelasan infromasi dan aspek penggunaan kalimat. Setelah direvisi maka produk divalidasi oleh ahli untuk diberi masukkan dan saran.

Tabel 2 : Hasil Uji Coba Sekala Kecil

\begin{tabular}{clcc}
\hline No & \multicolumn{1}{c}{ Aspek } & Setuju & Tidak Setuju \\
\hline 1. & Kepuasan Pengguna & $90 \%$ & $10 \%$ \\
2. & Efektifitas produk applikasi & $90 \%$ & $10 \%$ \\
3. & $\begin{array}{l}\text { Penggunaan } \\
\text { mudah digunakan }\end{array}$ & $10 \%$ \\
4. & $\begin{array}{l}\text { Informasi yang diberikan } \\
\text { jelas }\end{array}$ & $80 \%$ & $20 \%$ \\
5. Penggunaan kalimat pada & $80 \%$ & $20 \%$ \\
\hline
\end{tabular}

\section{Revisi Produk}

Hasil dari uji coba skala kecil dijadikan pedoman untuk melakukan revisi produk. Selain penilaian dari pemustaka dilakukan kembali validasi ahli media. Revisi ini dilakukan keseluruh aspek pada layanan SKBPP dengan Whatsapp; terutama pada kejelasan informasi dan pemahaman kalimat. Informasi yang diberikan mengenai layanan SKBPP kurang dimengerti oleh pemustaka; oleh sebab itu dilakukan sosialisasi lewat web site; pamlfet ataupun pengumuman di perpustakaan mengenai prosedur penggunaan layanan SKBPP dengan whatsapp. Pada aspek pemahaman kalimat dipilih kalimat yang spesifik dan mudah dipahami oleh pemustaka. 
204 | TIK ILMEU: Jurnal IImu Perpustakaan dan Informasi, vol. 4, no. 2, 2020
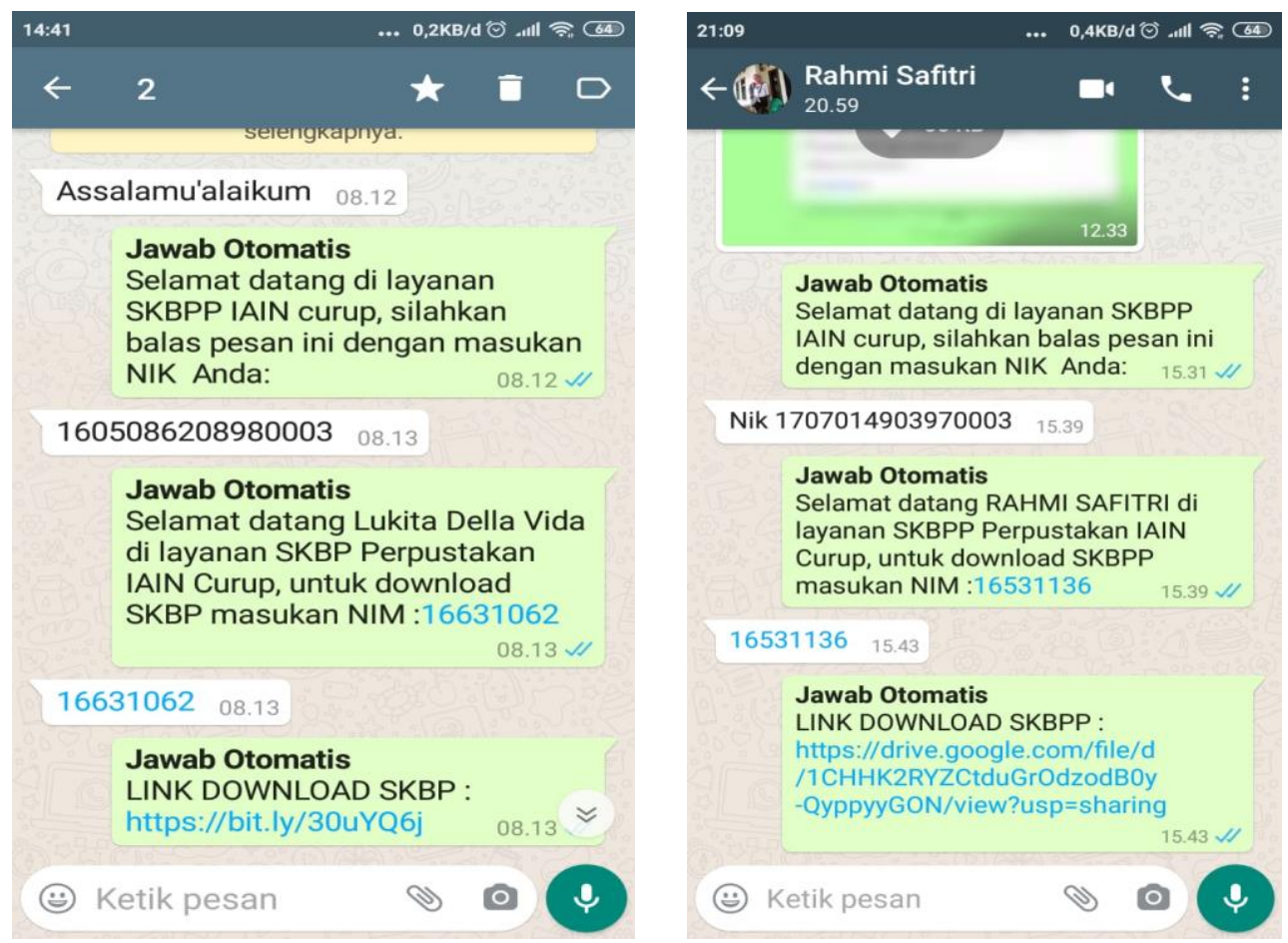

Gambar 2 : Layanan SKBPP dengan Whatsapp sebelum revisi (kiri) dan setelah direvisi (kanan)

\section{Uji Coba Skala Besar}

Setelah produk direvisi dan dianggap baik untuk digunakan; maka dilakukan uji coba yang kedua yaitu uji coba skala besar. Adapun objek observer dari uji coba skala besar adalah sebanyak 73 pemustaka. Pada uji coba skala besar intrumen dan metode yang digunakan sama dengan uji coba skala kecil. Hal ini dilakukan karena pengukuran atau validasi dibutuhkan alat ukur dan standar yang sama.

Berdasarkan uji coba skala besar dihasilkan pada aspek kepuasan pengguna layanan SKBPP dengan whatsapp 98;6 \% pemustaka setuju. Pada aspek ini terdapat kenaikan kepuasan pengguna layanan. Pada aspek efektifitas layanan SKBPP dengan whatsapp terdapata kenaikan repson diperoleh 96;9\% pemustaka setuju. Aspek kemudahaan penggunaan aplikasi mengalami kenaikan presentase dengan respon pemustaka setuju 97;3\%. Aspek kejelesan informasi mengalami kenaikan menjadi 95;9\% pemustaka 
setuju. Sedangkan aspek kemudahan kalimat dipahami mengalami kenaikan respon setuju pemustaka 97;3\%.

Tabel.3. Hasil Uji Coba Skala Besar

\begin{tabular}{clcc}
\hline No & \multicolumn{1}{c}{ Aspek } & Setuju & Tidak Setuju \\
\hline 1. & Kepuasan Pengguna & $98 ; 6 \%$ & $1 ; 4 \%$ \\
2. & Efektifitas produk & $95 ; 9 \%$ & $4 ; 1 \%$ \\
3. & $\begin{array}{l}\text { Penggunaan applikasi } \\
\text { mudah digunakan }\end{array}$ & $97 ; 3 \%$ & $2 ; 7 \%$ \\
4. & $\begin{array}{l}\text { Informasi yang diberikan } \\
\text { jelas }\end{array}$ & $95 ; 9 \%$ & $4 ; 1 \%$ \\
5. & $\begin{array}{l}\text { Penggunaan kalimat pada } \\
\text { pesan mudah dipahami }\end{array}$ & $97 ; 3 \%$ & $2 ; 7 \%$ \\
\hline
\end{tabular}

\section{Aplikasi Produk}

Produk yang telah dilakukan uji coba sekala besar dianalisis. Setelah dilakukan penyempurnaan terhadap layanan SKBPP menggunakan WhatsApp maka layanan ini dapat digunakan di perpustakan IAIN Curup.Penggunaan WhatsApp sebagai alternativ layanan SKBPP karena pengguna WhatsApp semakin tahun semakin meningkat. Pada Mei 2018 sebanyak 1;5 miliar dan sudah mengirim sebanyak 65 miliar pesan melalui aplikasi WhatsApp maupun WhatsApp web per harinya. Setahun setelah diakuisisi Facebook; trafik pesan yang dihasilkan pengguna WhatsApp dalam sehari mencapai 30 miliar pesan. Jumlah pesan yang dikirim ke seluruh dunia per hari seperti terlihat pada gambar Tahap Pengembangan Dan Penilaian Produk.

Jika produk memiliki kriteria yang layak digunakan maka dilaksanakan aplikasi produk. Akan tetapi jika produk tidak sesuai maka produk tidak digunakan. Maka dilakukan penelitian lanjut penyebab produk tidak layak digunakan.

\section{Pengembangan Layanan Perpustakaan IAIN Curup di Masa Pandemic Covid-19}

Di masa pandemic Covid-19 kedua bentuk layanan perpustakaan diubah menjadi online dan ada beberapa layanan ditutup. Oleh sebab itu; pustakawan dituntut untuk melakukan inovasi berbasis daring agar pelayanan perpustakaan tetap berjalan effektif dan optimal di masa pandemic Covid-19. 
Salah satu inovasi pelayanan perpustakaan yang dapat dilakukan adalah menggunakan aplikasi platform WhatsApp. Aplikasi ini merupakan alah satu aplikasi android yang paling banyak digunakan oleh masyarakat khususnya pemustaka. Sehingga; WhatsApp dapat digunakan sebagai alternatif layanan perpustakaan yang efektif. Aplikasi ini terdiri dari beberapa jenis.

Dari ketiga jenis WhatsApp di atas; inovasi layanan perpustakaan di IAIN Curup yang dapat digunakan adalah Auto WhatsApp yang dihubungkan dengan WhatsApp Business. Sebelum menggunakan kedua applikasi tersebut; database pemustaka dikelola terlebih dahulu menggunakan google spreadshreets. Setelah dikelola di google spreadsheets database tersebut disinkronkan dengan AutoWhatsApp dan WhatsApp Bussines.

Penggunaakn aplikasi Auto Whatsapp yang disinkronkan dengan database pemustaka dapat mempermudah pustakawan melayani pemustaka dan sebaliknya. Selain itu; tidak ada perpustakaan untuk memperoleh layanan perpustakaan di masa pandemic Covid-19. Cukup melakukan komunikasi dengan nomor Auto WhatsApp.

Salah satu layanan perpustakaan yang dapat menggunakan aplikasi platfrom Auto WhatsApp adalah untuk mendapatkan Surat Keterangan Bebas Pinjaman Perpustakaan (SKBPP). Sebelum mendapatkan SKBPP; pemustaka dalam hal ini adalah mahasiswa terlebih dahulu melengkapi persyaratannya. Seluruh persyaratan untuk memperoleh SKBPP dilakukan dengan cara dalam jaringan atau daring. Pemustaka wajib upload data melalui web peprustakaan IAIN Curup lib.iaincurup.ac.id; Seperti mengumpulkan Skripsi dalam bentuk PDF; dan bukti pembayaran sumbangan buku dalam bentuk JPG. Setelah persyaratan lengkap; pemustaka cukup mengirim chat dengan format NIK (Nomor Induk Kependudukkan) dan NIM (Nomor Induk Mahasiswa) pemustaka ke no Auto WhatsApp. Maka pemustaka akan mendapat balasan berupa link unduh SKBPP. Di bawah ini merupakan gambar penggunaan aplikasi Auto WhatsApp pada layanan SKBPP. 


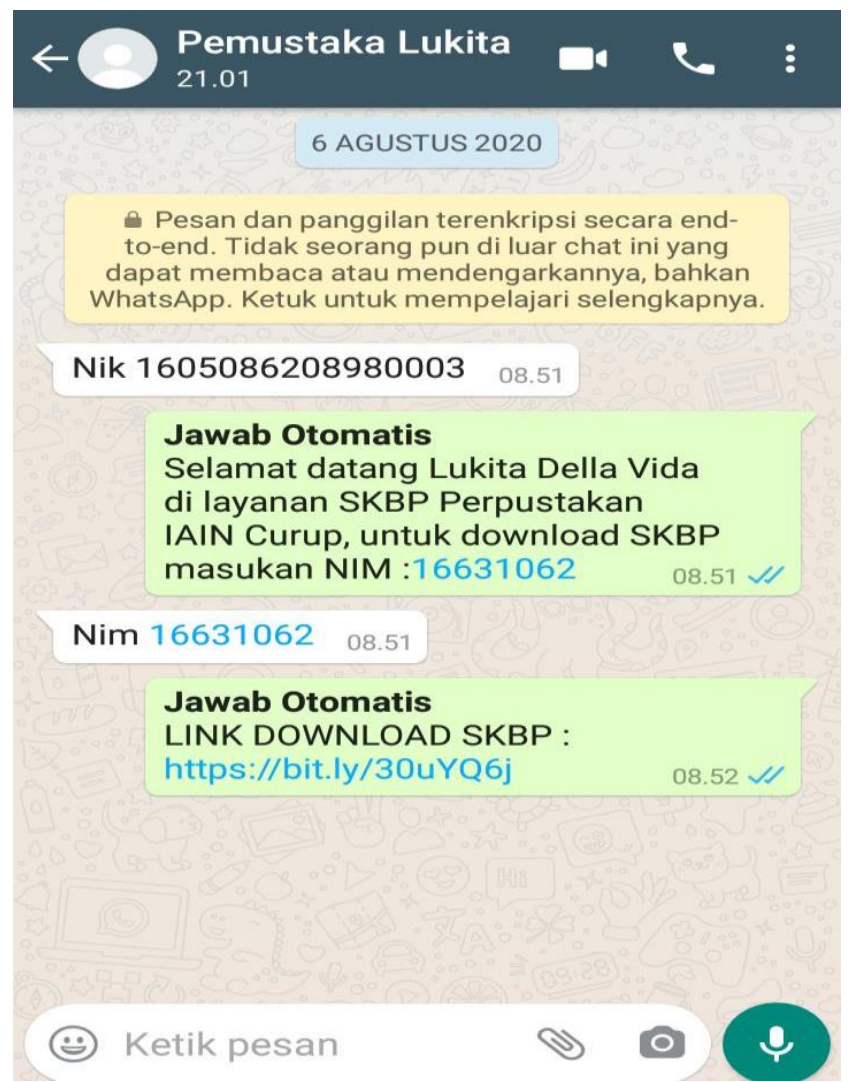

Gambar 3 : Contoh Penggunaan Aplikasi Auto WhatsApp pada layanan SKBPP.

Proses pembuatan dan sinkronisasi antara database dengan WhatsApp hanya memerlukan E-Mail admin; nomor Admin dan database pemustaka dalam bentuk excel. File SKBPP tiap pemustaka dijadikan satu pada sebuah folder dan disimpan di Google Drive Admin. Agar File dapat diunduh oleh pemustaka maka seluruh file SKBPP diubah menjadi "bagikan ke siapapun" . Agar link unduh singkat maka diubah melalui situs bitly; link unduh diletakkan di spredsheet database pemustaka.

Gambar di bawah ini adalah Spredsheet database yang disinkronkan ke Auto WhatsApp. 


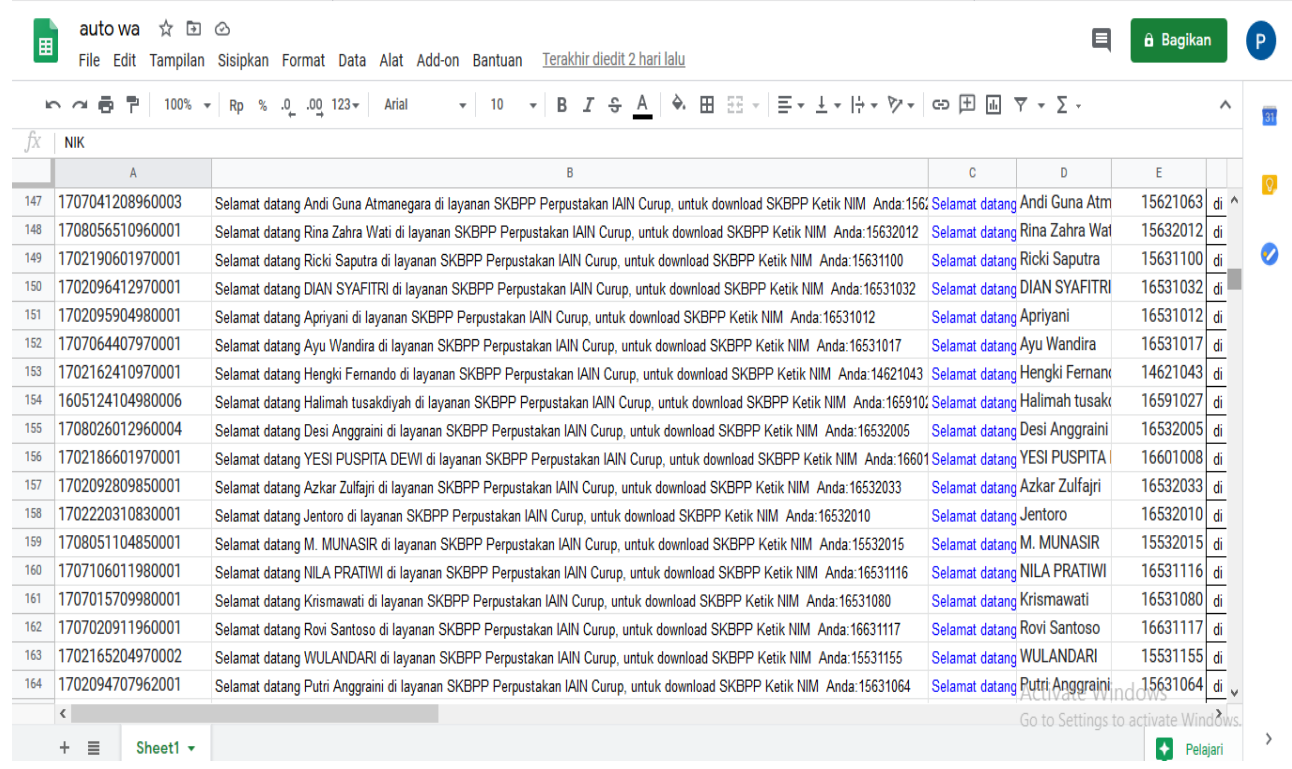

Gambar 4 : Database yang disinkronkan ke AutoWhatsApp

Setiap applikasi mempunyai kelebihan dan kekurangan. Adapun kelebihan dari penggunaan Auto WhatsApp untuk layanan SKBPP adalah :

1. Mempermudah pemustaka untuk memperoleh SKBPP sebagai syarat yudisium; pemustaka cukup mengirim pesan ke nomor admin. Setelah itu; pemustaka akan diarahkan ke link unduh SKBPP.

2. Tidak memerlukan biaya yang banyak untuk mengoperasikan aplikasi ini. Perpustakaan cukup menyediakan jaringan dan sebuah android untuk dijadikan HardWare dari aplikasi Auto WhatsApp.

Adapun kekurangan penggunaan aplikasi ini pada layanan SKBPP adalah :

1. Pembuatan link unduh di situs bitly dilakukan satu-satu sehingga memerlukan waktu lebih dalam proses pembuatan.

2. Pemustaka yang berada di kawasan tidak ada jaringan; otomatis tidak dapat menggunakan aplikasi ini untuk memperoleh SKBPP.

Wabah Covid-19 tidak menghambat layanan perpustakaan. Sebagai pustakawan tentu perlu menambah wawasan dan skill dalam bidang teknologi khususnya teknologi informasi. Karena dengan teknologi informasi; seluruh pekerjaan dapat dibuat menjadi efektif tanpa memandang jarak dan waktu.

\section{KESIMPULAN}


Kreativitas merupakan salah satu kemampuan yang harus dimiliki setiap pustakawan. dengan kreativitas pustakawan mampu menyelesaikan masalah dengan gagasan atau sebuah inovasi. Pemanfaatan aplikasi platform WhatsApp merupakan salah satu hasil dari berfikir kreatif. Memanfaatkan aplikasi yang banyak digunakan pemustakan sebagai salah satu solusi dari masalah terhambatnya layanan perpustakaan di masa pandemic Covid-19. Perpustakaan yang modern harus memanfaatkan secara optimal teknologi informasi. Oleh sebab itu; pustakawan bukan hanya memiliki kinerja kategori baik; akan tetapi mampu menggunakan teknologi informasi yang baik pula. yang bisa dimanfaatkan oleh pemustaka atau masyarakat luas.

Penggunaan WhatsApp untuk layanan SKBPP ini perlu dikembangkan lebih lanjut. Hal ini untuk mengurangi kekurangan dari penggunaan aplikasi WhatsApp. Selain itu; perlu pengembangan aplikasi platform android di perpustakaan IAIN Curup.

\section{DAFTAR RUJUKAN}

Andayani; T. R. (2009). Efektifitas Komunikasi Interpersonal . Semarang: UNDIP.

Arifin; Z. (2012). Model Penelitian dan Pengembangan. Bandung: PT Remaja Rosdakarya.

Hong; C. W.; Tak Hei Lam; E.; \& KW Chiu; D. (2020). Social media as a platform in academic library marketing: A comparative study. The Journal of Academic Librarianship :. 46 ; 46.

Jones; M.; \& Harvey; M. (2016). The effectiveness of social media as amarketing tool for libraries in educational institutions. Journal of Librarianship and Information Science; 3-19.

Karim; A. M.; \& zakiyah; E. (2019). Pemanfaatan Layanan Perpustakaan Online di Indonesia. Jurnal PUBLIS Vol.2 No.1; . UIN Syarif Hidayatullah; Jakarta.

Larasati; W. (2013). Efektivitas Pemanfaatan Aplikasi WhatsApp sebagai Sarana Diskusi Pembelajaran Pada Mahasiswa (UIN Sunan Kalijaga Yogyakarta).

Nashihudin; W. (2016; Nashihudin; Wahid. (2016). ). Membudayakan Knowledge di Perpustakaan. Retrieved from www.researchgate.net: http://www.researchgate.net/publications/305637953/.LIPI. 
210 | TIK ILMEU: Jurnal IImu Perpustakaan dan Informasi, vol. 4, no. 2, 2020

Pranajaya; W. H. (2017). Pemanfaatan aplikasi whatsapp (WA) Dikalangan pelajar (Studi kasus Di MTS Almuddatsiriyah dan MTS Jakarta Pusat) . jurnal sosial; ekonomi dan humaniora : UNISBA Bandung.

Rhoni; R. (2017). Pustakawan Profesional di Era Digital. Yogyakarta: Suluh Media.

Sugiyono. (2009). Metode Penelitian Kuantitatif Kualitatif danR\& D. Bandung : Alfabeta. 